\title{
ACCIDENTS WITH POISONOUS ANIMALS IN BRAZIL BY AGE AND SEX
}

\author{
Ageane Mota da Silva ${ }^{1}$, Paulo Sérgio Bernarde ${ }^{2}$, Luiz Carlos de Abreu ${ }^{3}$
}

DOI: http://dx.doi.org/10.7322/jhgd.96768

\begin{abstract}
Introduction: accidents with poisonous animals are a common clinical emergency in several tropical countries, mainly in the fields and rural areas, constituting a public health problem, including pediatric. Objective: The objective is to analyze the morbidity, mortality and lethality according to age and sex in cases of poisoning by snakes, scorpions and spiders in Brazil. Methods: data on poisoning by snakes, scorpions and spiders that occurred from 2009 to 2013 were collected in the online database of the Information System on Diseases of Compulsory Declaration (SINAN) of the Ministry of Health. Results: were recorded 28.812 cases of snake bites per year, $60.370,8$ with scorpions and $25.786,4$ with spiders. Most deaths were caused by snakes (119 per year) and also showed higher lethality $(0.41 \%)$, followed by scorpions ( 79.6 deaths) with a lethality of $0.13 \%$ and spiders $(13.2)$ and the lowest mortality $(0.05 \%)$. In males individuals were most cases of snake bites, whereas in accidents scorpions and spiders was observed little difference in frequency between men and women. The age group with the largest number of poisonings records was 20-39 years. Conclusions: there is a progressive increase in cases of poisoning from the first year of age until the age range 20-39 years, and after this, begins a decrease in cases. Children, adolescents and elderly adults are most vulnerable because they have higher lethality rates, especially in the snake and scorpion accidents.
\end{abstract}

Key words: snake bites, ophidism, scorpionism, araneism.

\section{INTRODUCTION}

Accidental poisoning by venomous animals is a common clinical emergency in several tropical countries, mainly in the fields and rural areas of Latin America, Africa, Asia and Oceania. ${ }^{1,2}$ In Brazil, during the year 2013, health officials recorded 158,002 cases of poisoning by venomous animals; of these, the majority $(123,128$ cases) was caused by snakes, scorpions, and spiders. ${ }^{3}$ Poisoning by venomous animals and their consequences constitute a public health problem and, in particular, a paediatric concern in many countries. ${ }^{1}$

The World Health Organization (WHO) in 2009 included snakebite on its Neglected Tropical Diseases List. $^{2}$ It is estimated that 1.841 million cases of poisoning occur every year on the planet, resulting in 94,000 deaths. In Brazil, poisoning by snakes represents approximately 29,000 cases per year, an average of 125 deaths. ${ }^{4}$ Regarding arachnids, there were 69,036 cases of people bitten by scorpions in 2013, resulting in 80 deaths and 27,125 cases of poisoning by spiders, from which 36 died. $^{3}$
There are 62 species of venomous snakes known in Brazil, ${ }^{4}$ which are classified into four groups: Bothropic (Genus Bothrops and Bothrocophias - lanceheads, responsible for $86.23 \%$ of cases); Crotalic (Genus Crotalus rattlesnakes, accounting for $9.17 \%$ of cases); Lachetic (Genus Lachesis - bushmaster, accounting for $3.72 \%$ of cases); Elapidic (Genus Micrurus - coral snake, responsible for $0.86 \%$ of cases). The epidemiological profile of snakebite victims is a rural male worker between the ages of 15 to 49 , usually affected on the lower limbs. ${ }^{5,6}$ The lethality of snakebite is $0.44 \%,{ }^{4}$ and there is an association between the severity of cases and age (children under 10 years and older adults experience the worst consequences). . $^{7-9}$

The scorpions of medical interest in Brazil belong to the genus Tityus; three main species are responsible for serious, even fatal, poisonings in humans in the South, Southeast, Midwest and Northeast Brazil6,10: T. bahiensis (brazilian scorpion), $T$. serrulatus (yellow scorpion) and $T$. stigmurus.

\footnotetext{
1 Instituto Federal de Educação Ciência e Tecnologia do Acre. Cruzeiro do Sul - Acre.

2 Universidade Federal do Acre, Campus Floresta, Laboratório de Hepetologia, Cruzeiro do Sul - Acre.

2 Faculdade de Medicina do ABC - Departamento de Saúde Coletiva. São Paulo- SP.

Corresponding author: ageane.silva@ifac.edu.br
}

Suggested citation: Mota da Silva A (2015), Bernarde PS, Abreu LC. Accidents with poisonous animals in Brazil by age and sex. Journal of Human Growth and Development. 25(1): 54-62

Manuscript submitted May 08 2014, accepted for publication Oct 292014. 
Two species (Tityus metuendus and T. obscurus) are known in the Amazon and stand out due to their potential for serious harm to humans. ${ }^{11}$ Accidents with scorpions show little difference between men and women with a lethality of $0.2 \%$. Children under 10 years are the most vulnerable group. ${ }^{6}$.

In Brazil, the Ministry of Health is mainly interested in the next three genera of spiders $^{6,12}$ : Phoneutria (wandering spider), Loxosceles (brown spider) and Latrodectus (widow spider). The most important form of poisoning by spider in Brazil is the bite of the brown spider brown (Loxosceles), which presents the most lethal poison (lethality rate of $0.05 \%$ ) and is responsible for the most accidents (loxoscelism) in the south of the country. Most accidents occur in young adults and women experience a higher prevalence of cases, while men are more affected in cases of phoneutrism (Phoneutria) and latrodectism (Latrodectus).

The objective is to analyze the morbidity, mortality and lethality according to age and sex in cases of poisoning by snakes, scorpions and spiders in Brazil.

\section{METHODS}

This is a descriptive and retrospective study analysing an online database, the Information System of Notifiable Diseases (SINAN) from the Ministry of Health ${ }^{3}$ where the accidents by poisonous animals that occur in the country are recorded. The SINAN record, accessible in hospitals, has 64 variables of which 21 are available online. From these online variables, we considered the following for this study: the kind of causative animal (snake, scorpion, or spider), distribution of poisoning by snake genus (Bothrops, Crotalus, Lachesis, and Micrurus) and spider genus (Phoneutria, Loxosceles, and Latrodectus ), age and sex of the victim, pregnant women, and deaths. The cases of poisoning by snakes, spiders and scorpions between the years 2009 and 2013 were recorded. The data collected were grouped into Excel spreadsheets to make the calculations of means, percentage, and lethality. Lethality rate was obtained by dividing the number of deaths that occurred due to the certain type of poisoning by the number of cases registered by the same type of accident and then multiplying by 100 . The result was expressed as a percentage.

\section{RESULTS}

A total of 144,060 snakebites (mean of 28,812 cases per year), 301,854 accidents involving scorpions (mean of $60,370.8$ cases per year) and 128,932 accidents with spiders (mean 25,786.4 cases per year) were recorded between 2009 and 2013 (Tables 1, 2, and 3). Most deaths were caused by snakes (mean of 119 per year), which also showed higher lethality $(0.41 \%)$, followed by scorpions (mean of 79.6 deaths per year) with a lethality rate of $0.13 \%$ and spiders (13.2 deaths per year), the lowest lethality $(0.05 \%)$. Most cases of snakebites (76.9\% of cases) involved males, while only a little difference in frequency was observed when comparing men and women in accidents with scorpions and spiders (Figure 1 ). The largest number of poisonings by snakes, scorpions and spiders occurred to people between 20 and 39 years old, followed by those 40 to 59 years old (Tables 1, 2, and 3; Figure 2).

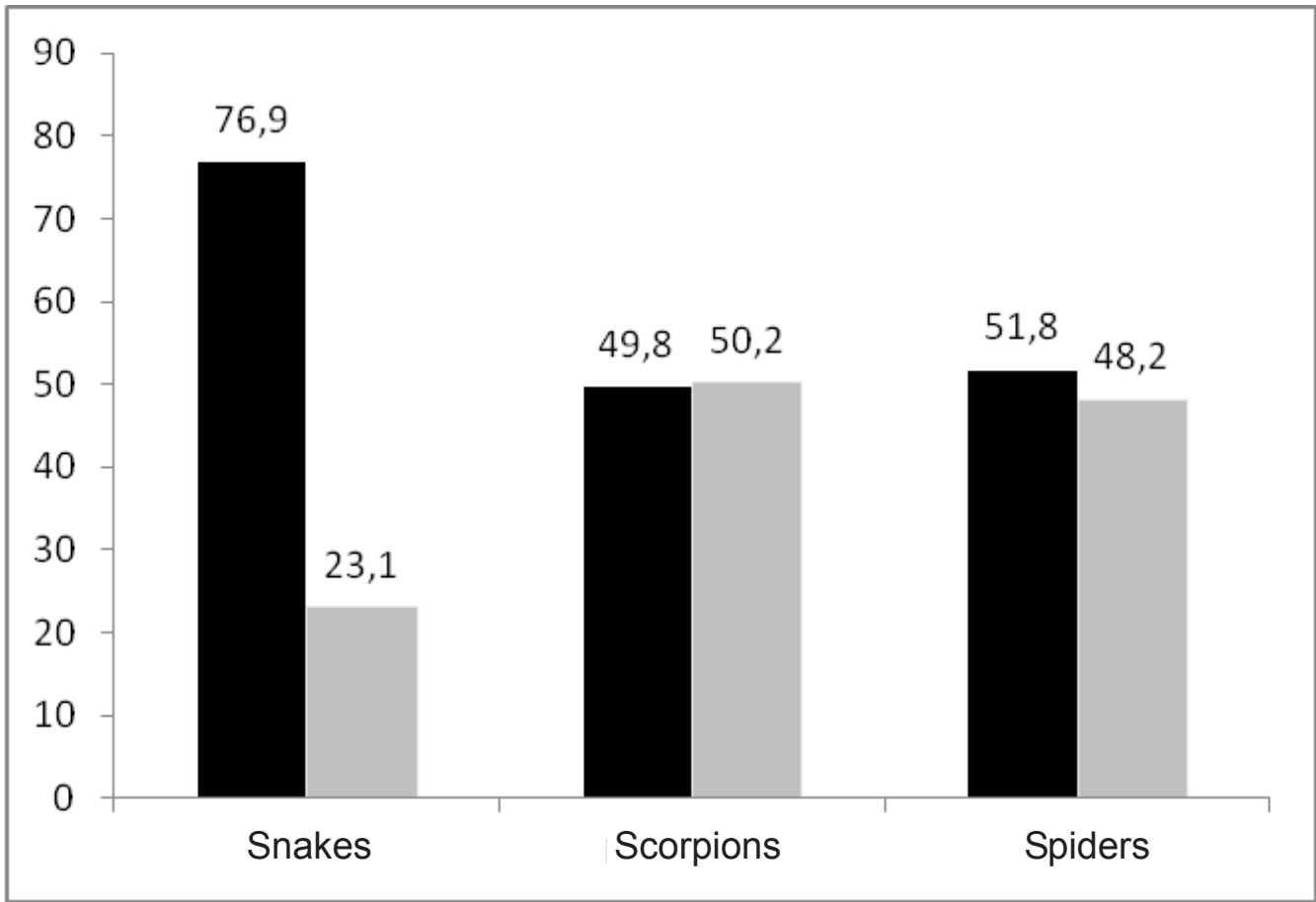

Figure 1: Proportion of male (black columns) and female (grey columns) individuals in accidents by snakes $(144,060$ cases), scorpions $(301,854)$, and spiders $(128,932)$ in Brazil during the years 2009 to 2013 (total number of cases). 
Table 1: Distribution of cases (= no.), deaths and lethality (= LET) for snakebites per age group and sex in Brazil - mean of the period 2009 to 2013 (Source: SINAN / SVS / MS ${ }^{3}$ )

\begin{tabular}{|c|c|c|c|c|c|c|c|c|c|c|}
\hline Age & no. & $\%$ & DEATHS & LET & no. & $\%$ & LET & no. & $\%$ & LET \\
\hline$<1$ & 334.2 & 1.15 & 1.2 & $0.35 \%$ & 260 & 1.18 & 0.46 & 74 & 1.11 & 0 \\
\hline $1-4$ & 566.2 & 1.96 & 2.6 & $0.45 \%$ & 336.8 & 1.52 & 0.59 & 229.4 & 3.45 & 0.26 \\
\hline $5-9$ & 1.431 .8 & 4.96 & 5.4 & $0.37 \%$ & 923.8 & 4.16 & 0.45 & 508 & 7.63 & 0.23 \\
\hline $10-14$ & 2.502 .6 & 8.68 & 8 & $0.31 \%$ & 1.815 .6 & 8.2 & 0.33 & 686.6 & 10.32 & 0.29 \\
\hline $15-19$ & 2.839 & 9.85 & 4.8 & $0.16 \%$ & 2.222 .6 & 10.05 & 0.13 & 616.2 & 9.26 & 0.29 \\
\hline $20-39$ & 10.164 .6 & 35.27 & 29.8 & $0.29 \%$ & 8.097 .4 & 36.55 & 0.31 & 2.065 .8 & 31.06 & 0.22 \\
\hline $40-59$ & 8.046 .2 & 27.9 & 38.2 & $0.47 \%$ & 6.227 & 28.1 & 0.49 & 1.817 .6 & 27.34 & 0.41 \\
\hline $60-64$ & 1.170 .4 & 4.06 & 8.2 & $0.7 \%$ & 921.2 & 4.15 & 0.56 & 249 & 3.75 & 1.2 \\
\hline 65-69 & 785.2 & 2.72 & 3.8 & $0.48 \%$ & 616.2 & 2.78 & 0.48 & 169 & 2.55 & 0.47 \\
\hline $70-79$ & 765.2 & 2.65 & 12.6 & $1.64 \%$ & 582.6 & 2.62 & 1.61 & 182.6 & 2.75 & 1.75 \\
\hline$>80$ & 202.8 & 0.7 & 4.4 & $2.16 \%$ & 150.8 & 0.68 & 1.98 & 51.8 & 0.78 & 2.7 \\
\hline Unknown & 3.8 & 0.01 & 0 & 0 & 3.2 & 0.01 & & 0.4 & 0.006 & \\
\hline \multicolumn{11}{|l|}{ Sex } \\
\hline Man & 22.157 & 76.9 & 92.8 & $0.41 \%$ & & & & & & \\
\hline Woman & 6.650 .4 & 23.08 & 26.2 & $0.39 \%$ & & & & & & \\
\hline Unknown & 4.6 & 0.01 & 0 & 0 & & & & & & \\
\hline Pregnant & 149.8 & 0.51 & 2 & $1.33 \%$ & & & & & & \\
\hline Total & 28.812 & 100 & 119 & $0.41 \%$ & 22.157 .2 & 100 & & 6.650 .4 & 100 & \\
\hline
\end{tabular}

Table 2: Distribution of cases (= no.), deaths and lethality (= LET) by scorpion according to age and sex in Brazil - mean of the period 2009 to 2013 (Source: SINAN / SVS / MS ${ }^{3}$ )

\begin{tabular}{|c|c|c|c|c|c|c|c|c|c|c|}
\hline Age & no. & $\%$ & DEATHS & LET & no. & $\%$ & LET & no. & $\%$ & LET \\
\hline$<1$ & 809.4 & 1.35 & 1.6 & $0.19 \%$ & 432.6 & 1.44 & 0.18 & 376.6 & 1.24 & 0.21 \\
\hline $1-4$ & 2.875 .4 & 4.76 & 17.2 & $0.59 \%$ & 1.547 .6 & 5.15 & 0.68 & 1.327 .6 & 4.38 & 0.49 \\
\hline $5-9$ & 3.819 .6 & 6.32 & 13.8 & $0.36 \%$ & 1.981 .6 & 6.60 & 0.30 & 1.837 .4 & 6.06 & 0.42 \\
\hline $10-14$ & 4.549 .8 & 7.54 & 6.4 & $0.14 \%$ & 2.314 .8 & 7.70 & 0.13 & 2.234 .4 & 7.37 & 0.14 \\
\hline $15-19$ & 5.135 .2 & 8.50 & 4.6 & $0.08 \%$ & 2.526 .4 & 8.40 & 0.06 & 2.608 & 8.60 & 0.11 \\
\hline $20-39$ & 20.073 .4 & 33.25 & 17.6 & $0.08 \%$ & 10.218 & 34 & 0.10 & 9.852 & 32.50 & 0.07 \\
\hline $40-59$ & 15.367 .6 & 25.45 & 11 & $0.07 \%$ & 7.492 .6 & 24.94 & 0.08 & 7.872 .8 & 25.97 & 0.06 \\
\hline $60-64$ & 2.603 .8 & 4.32 & 2.4 & $0.09 \%$ & 1.258 .6 & 4.18 & 0.09 & 1.345 .2 & 4.44 & 0.08 \\
\hline $65-69$ & 1.917 .2 & 3.18 & 1.6 & $0.08 \%$ & 898.8 & 3 & 0.06 & 1.018 .2 & 3.36 & 0.09 \\
\hline $70-79$ & 2.372 .2 & 3.92 & 2.2 & $0.09 \%$ & 1.032 .8 & 3.44 & 0.13 & 1.338 .8 & 4.42 & 0.05 \\
\hline$>80$ & 834.8 & 1.39 & 1.2 & $0.14 \%$ & 338 & 1.13 & 0.05 & 496.6 & 1.64 & 0.16 \\
\hline Unknown & 12.4 & 0.02 & 0 & 0 & 6.20 & 0.02 & & 6.2 & 0.02 & \\
\hline \multicolumn{11}{|l|}{ Sex } \\
\hline Man & 30.048 & 49.78 & 42.6 & $0.14 \%$ & & & & & & \\
\hline Woman & 30.313 .8 & 50.21 & 37 & $0.12 \%$ & & & & & & \\
\hline Unknown & 9 & 0.01 & 0 & & & & & & & \\
\hline Pregnant & 623 & 1.03 & 1 & $0.16 \%$ & & & & & & \\
\hline Total & 60.370 .8 & 100 & 79.6 & $0.13 \%$ & 30.048 & 100 & & 30.313 .8 & 100 & \\
\hline
\end{tabular}

Table 3: Distribution of cases (= no.), deaths and lethality (= LET) by spiders by age and sex in Brazil mean of the period 2009 to 2013 (Source: SINAN / SVS / MS ${ }^{3}$ )

\begin{tabular}{|c|c|c|c|c|c|c|c|c|c|c|}
\hline & & & & & & & & & \multirow[b]{2}{*}{$\%$} & \multirow[b]{2}{*}{ LET } \\
\hline Age & no. & $\%$ & DEATHS & LET & no. & $\%$ & LET & no. & & \\
\hline$<1$ & 320 & 1.250 & 0.2 & 0.06 & 174.6 & 1.30 & 0 & 145.2 & 1.18 & 0.13 \\
\hline $1-4$ & 1.234 .4 & 4.800 & 0.8 & 0.06 & 681.8 & 5.10 & 0 & 552.6 & 4.45 & 0.14 \\
\hline $5-9$ & 1.193 & 4.630 & 0.6 & 0.05 & 649.8 & 4.86 & 0 & 542.6 & 4.38 & 0.11 \\
\hline $10-14$ & 1.338 .6 & 5.200 & 0.6 & 0.04 & 754.4 & 5.65 & 0 & 583.8 & 4.7 & 0.03 \\
\hline $15-19$ & 1.974 .6 & 7.700 & 1.2 & 0.06 & 981 & 7.35 & 0.04 & 993.6 & 8 & 0.06 \\
\hline $20-39$ & 8.700 .6 & 33.800 & 3.2 & 0.03 & 4291.2 & 32.10 & 0.02 & 4407.6 & 35.5 & 0.03 \\
\hline $40-59$ & 7.502 & 29.200 & 3.4 & 0.04 & 3811.8 & 28.52 & 0.03 & 3688.2 & 29.7 & 0.04 \\
\hline $60-64$ & 1.250 .4 & 4.900 & 1 & 0.07 & 716.2 & 5.35 & 0.08 & 534 & 4.3 & 0.03 \\
\hline $65-69$ & 930.4 & 3.300 & 1 & 0.10 & 539.6 & 4.04 & 0.07 & 390.4 & 3.15 & 0.15 \\
\hline $70-79$ & 1.049 .6 & 4.100 & 0.6 & 0.05 & 609.2 & 4.56 & 0.03 & 440.2 & 3.55 & 0.09 \\
\hline$\geq 80$ & 287.4 & 1.120 & 0.6 & 0.2 & 153.6 & 1.15 & 0.13 & 133.8 & 1.08 & 0.29 \\
\hline Unknown & 5.2 & 0.002 & 0 & 0 & 3 & 0.02 & 0 & 2.2 & 0.01 & 0 \\
\hline \multicolumn{11}{|l|}{ Sex } \\
\hline Man & 13.366 .2 & 51.84 & 5.8 & 0.04 & & & & & & \\
\hline Woman & 12.414 .2 & 48.15 & 7.4 & 0.05 & & & & & & \\
\hline Unknown & 5.8 & 0.02 & 0 & & & & & & & \\
\hline Pregnant & 228.8 & 0.88 & 0 & 0 & & & & & & \\
\hline Total & 25.786 .2 & 100 & 13.2 & 0.05 & 13.366 .2 & 100 & & 12.414 .2 & 100 & \\
\hline
\end{tabular}




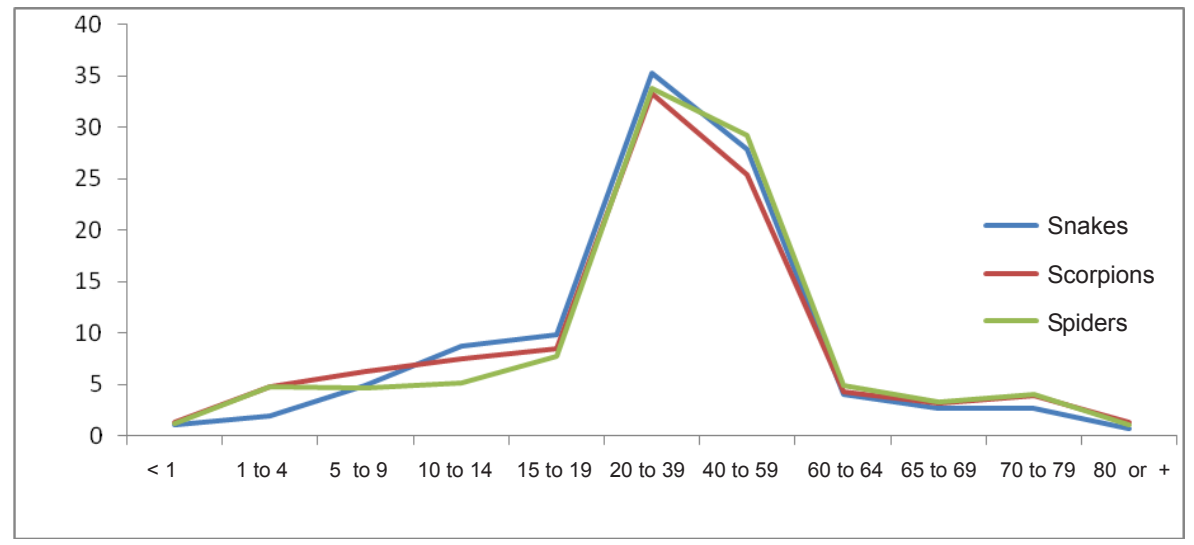

Figure 2: Distribution of percentage of accidents with snakes, scorpions, and spiders by age group in Brazil from 2009 to 2013

Regarding snakebites, there is a progressive increase in poisonings from the first year of age until the age of 20-39 years; after this, the number of cases begins to decline. A higher number of deaths were registered for individuals from 20 to 59 years (average of 68 deaths per year $=57.14 \%$ ) and a higher lethality occurred after 60 years old $(0.7 \%$ lethality) (Table 1$)$. The highest lethality rates were observed between ages $70-79$ years $(1.64 \%)$ and over 80 years $(2.16 \%)$. In pregnant women $(0.5 \%$ of snakebites recorded), a higher lethality $(1.33 \%)$ was observed in relation to lethality in women $(0.39 \%)$.

Most cases of poisoning by snakes were bothropic accidents ( $86.2 \%$ ) (Table 4 ) followed by crotalic ( $9 \%)$, lachetic $(3.9 \%)$, and elapidic (0.9\%)

Table 4: Distribution of types of snake bites according to age group (total number of cases from 2009 to 2013) (Source: SINAN / SVS / MS ${ }^{3}$ )

\begin{tabular}{|c|c|c|c|c|c|c|c|c|}
\hline $\begin{array}{c}\text { Age } \\
\text { group }\end{array}$ & $\begin{array}{l}\text { Bothropic } \\
\text { no. cases }\end{array}$ & $\begin{array}{c}\text { Bothropic } \\
\%\end{array}$ & $\begin{array}{c}\text { Crotalic } \\
\text { no. cases }\end{array}$ & $\begin{array}{c}\text { Crotalic } \\
\%\end{array}$ & $\begin{array}{l}\text { Lachetic } \\
\text { no. cases }\end{array}$ & $\begin{array}{c}\text { Lachetic } \\
\%\end{array}$ & $\begin{array}{c}\text { Elapidic } \\
\text { no. cases }\end{array}$ & $\begin{array}{c}\text { Elapidic } \\
\%\end{array}$ \\
\hline $\begin{array}{c}<1 \\
1-4 \\
5-9 \\
10-14 \\
15-19 \\
20-39 \\
40-59 \\
60-64 \\
65-69 \\
70-79 \\
>80\end{array}$ & $\begin{array}{c}1,186 \\
1,845 \\
5,058 \\
9,028 \\
10,253 \\
37,047 \\
29,593 \\
4,363 \\
2,837 \\
2,774 \\
739\end{array}$ & $\begin{array}{c}1.14 \\
1.76 \\
4.83 \\
8.63 \\
9.80 \\
35.38 \\
28.25 \\
4.16 \\
2.70 \\
2.65 \\
0.70\end{array}$ & $\begin{array}{c}115 \\
171 \\
468 \\
709 \\
905 \\
3.731 \\
3.502 \\
494 \\
383 \\
375 \\
80\end{array}$ & $\begin{array}{c}1.05 \\
1.56 \\
4.28 \\
6.48 \\
8.28 \\
34.13 \\
32.04 \\
4.52 \\
3.5 \\
3.43 \\
0.73\end{array}$ & $\begin{array}{c}58 \\
73 \\
286 \\
519 \\
536 \\
1.814 \\
1.065 \\
166 \\
104 \\
95 \\
22\end{array}$ & $\begin{array}{c}1.22 \\
1.55 \\
6.03 \\
10.95 \\
11.33 \\
38.28 \\
22.48 \\
3.5 \\
2.2 \\
2 \\
0.46\end{array}$ & $\begin{array}{c}12 \\
55 \\
41 \\
65 \\
97 \\
447 \\
293 \\
45 \\
14 \\
30 \\
8\end{array}$ & $\begin{array}{c}1.08 \\
4.95 \\
3.70 \\
5.87 \\
8.85 \\
40.37 \\
26.46 \\
4.05 \\
1.25 \\
2.70 \\
0.72\end{array}$ \\
\hline Total & $\begin{array}{l}104.723 \\
(86.2 \%)\end{array}$ & 100 & $\begin{array}{c}10.933 \\
(9 \%)\end{array}$ & 100 & $\begin{array}{c}4.738 \\
(3.9 \%)\end{array}$ & 100 & $\begin{array}{c}1.107 \\
(0.9 \%)\end{array}$ & 100 \\
\hline
\end{tabular}

accidents. A larger number of cases of elapidic poisoning was observed $(4.95 \%)$ in children 1 to 4 years of age when compared to the frequency of poisonings with other types of snakes in this age group (bothropic, $1.76 \%$; crotalic, $1.56 \%$; lachetic $1.55 \%)$. The highest lethality was recorded in crotalic poisonings $(0.96 \%)$ (Table 5 ) followed by lachetic $(0.61 \%)$, bothropic $(0.37 \%)$, and elapidic $(0.27 \%)$. The four types of poisoning showed a higher incidence of lethality in individuals over 60 years old. All types of poisoning predominated in males (Figure 3), In relation to the victim's sex and the type of snake, there were differences in the proportion of victims as follows: lachetic

Table 5: Distribution of deaths and lethality (= LET) by types of snakebites according to age group (total number of obits from 2009 to 2013) (Source: SINAN / SVS / MS ${ }^{3}$ )

\begin{tabular}{|c|c|c|c|c|c|c|c|c|}
\hline $\begin{array}{l}\text { Age } \\
\text { Group }\end{array}$ & $\begin{array}{l}\text { Bothropic } \\
\text { deaths \% }\end{array}$ & $\begin{array}{c}\text { Bothropic } \\
\text { Let. }\end{array}$ & $\begin{array}{l}\text { Crotalic } \\
\text { deaths \% }\end{array}$ & $\begin{array}{l}\text { Crotalic } \\
\text { Let. }\end{array}$ & $\begin{array}{l}\text { Lachetic } \\
\text { deaths \% }\end{array}$ & $\begin{array}{c}\text { Lachetic } \\
\text { Let. }\end{array}$ & $\begin{array}{c}\text { Elapidic } \\
\text { deaths \% }\end{array}$ & $\begin{array}{c}\text { Elapidic } \\
\text { Let. }\end{array}$ \\
\hline $\begin{array}{c}<1 \\
1-4 \\
5-9 \\
10-14 \\
15-19 \\
20-39 \\
40-59 \\
60-64 \\
65-69 \\
70-79 \\
\geq 80\end{array}$ & $\begin{array}{c}3(0.76) \\
10(2.57) \\
17(4.36) \\
25(6.42) \\
13(3.33) \\
101(25.9) \\
134(34.36) \\
26(6.66) \\
11(2.83) \\
40(10.25) \\
10(2.56)\end{array}$ & $\begin{array}{l}0.25 \\
0.54 \\
0.33 \\
0.27 \\
0.12 \\
0.27 \\
0.45 \\
0.59 \\
0.38 \\
1.44 \\
1.35\end{array}$ & $\begin{array}{c}2(1.88) \\
1(0.95) \\
6(5.66) \\
6(5.66) \\
7(6.6) \\
17(16.04) \\
34(32.08) \\
6(5.66) \\
6(5.66) \\
13(12.26) \\
8(7.55)\end{array}$ & $\begin{array}{l}1.73 \\
0.58 \\
1.28 \\
0.84 \\
0.77 \\
0.45 \\
0.97 \\
1.21 \\
1.56 \\
3.46 \\
10\end{array}$ & $\begin{array}{c}1(3.44) \\
1(3.44) \\
1(3.44) \\
3(10.36) \\
0(0) \\
14(48.3) \\
5(17.26) \\
1(3.44) \\
1(3.44) \\
1(3.44) \\
1(3.44)\end{array}$ & $\begin{array}{l}1.72 \\
1.36 \\
0.34 \\
0.57 \\
0 \\
0.77 \\
0.46 \\
0.6 \\
0.96 \\
1.05 \\
4.54\end{array}$ & $\begin{array}{c}0(0) \\
0(0) \\
0(0) \\
1(33.33) \\
0(0) \\
1(33.33) \\
0(0) \\
1(33.33) \\
0(0) \\
0(0) \\
0(0)\end{array}$ & $\begin{array}{c}0 \\
0 \\
0 \\
1.53 \\
0 \\
0.22 \\
0 \\
2.22 \\
0 \\
0 \\
0\end{array}$ \\
\hline Total & $390(100)$ & 0.37 & $106(100)$ & 0.96 & $29(100)$ & 0.61 & $3(100)$ & 0.27 \\
\hline
\end{tabular}


(81.76\%); crotalic $(80.73 \%)$; bothropic (77.58\%); and elapidic (71.06\%) accidents.

There was also an increase in cases of poisoning as victims' age increased in accidents with scorpions and spiders. The majority of accidents were recorded between 20 and 39 years old and a reduced frequency was observed in later years (Table 2 and 3). Most deaths (mean of 32.6 per year $=41 \%$ ) and lethality rates in scorpion accidents was observed in children under nine years of age.

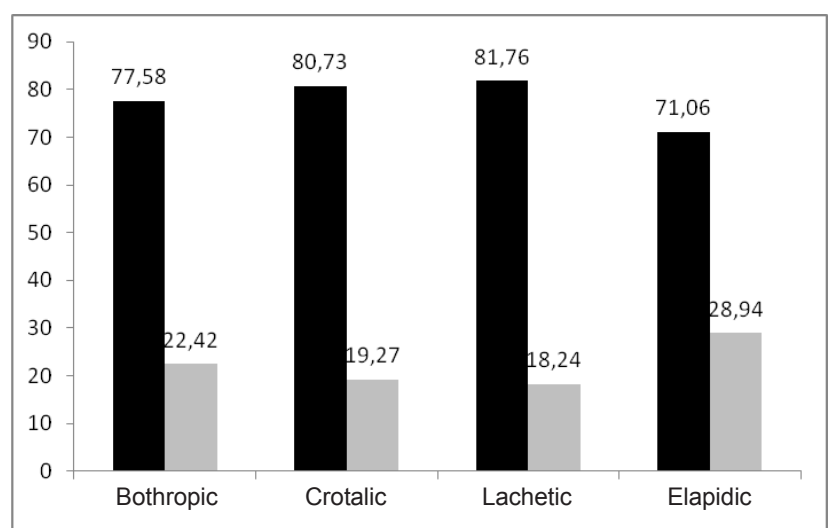

Figure 3: Proportion of male (black columns) and female (grey columns) individuals with snakebites (bothropic $=104,722$ cases; crotalic $=10,933$ cases; lachetic = 4,737 cases; elapidic $=1,106$ cases) in Brazil from 2009 to 2013 (total numbers).

Poisoning by spiders has a higher death frequency in adults aged between 20 and 59 years (mean of 6.6 deaths per year $=50 \%$ ).

Of the 128,932 cases of accidents with spiders during 2009-2013, only 59,700 (46.3\%) had recorded the genus of the spider (Tables 6 and $7)$. Most cases corresponded to loxoscelism (66.3\%) followed by phoneutrism (32.8\%) and latrodectism $(0.9 \%)$. During the study period, 66 deaths were due to poisoning by spiders of which only 24 recorded the genus of the spider. Most of deaths were attributed to the genus Loxosceles (lethality $0.04 \%$ ) followed by Phoneutria with 5 deaths $(0.02 \%)$ and Latrodectus with one $(0.17 \%)$. The majority of the victims in accidents with Phoneutria (59.42\% of cases) and Latrodectus (55.35\%) were male individuals, while females had a higher incidence of cases with Loxosceles (56.4\%) (Figure 4).

Table 6: Distribution of types of accidents and type of causer spider according to age group (total number of cases from 2009 to 2013) (Source: SINAN / SVS / MS 3 ).

\begin{tabular}{|c|c|c|c|c|c|c|}
\hline $\begin{array}{l}\text { Age } \\
\text { group }\end{array}$ & $\begin{array}{c}\text { Phoneutria } \\
\text { no. cases }\end{array}$ & $\begin{array}{c}\text { Phoneutria } \\
\%\end{array}$ & $\begin{array}{l}\text { Loxosceles } \\
\text { no. cases }\end{array}$ & $\begin{array}{c}\text { Loxosceles } \\
\%\end{array}$ & $\begin{array}{l}\text { Latrodectus } \\
\text { no. cases }\end{array}$ & $\begin{array}{c}\text { Latrodectus } \\
\%\end{array}$ \\
\hline $\begin{array}{c}<1 \\
1-4 \\
5-9 \\
10-14 \\
15-19 \\
20-39 \\
40-59 \\
60-64 \\
65-69 \\
70-79 \\
>80\end{array}$ & $\begin{array}{c}179 \\
710 \\
833 \\
888 \\
1,252 \\
5,605 \\
6,325 \\
1,206 \\
1,027 \\
1,193 \\
305\end{array}$ & $\begin{array}{c}0.92 \\
3.64 \\
4.26 \\
4.55 \\
6.41 \\
28.71 \\
32.4 \\
6.18 \\
5.26 \\
6.11 \\
1.56\end{array}$ & $\begin{array}{c}448 \\
1.911 \\
1.745 \\
1.858 \\
3.230 \\
15.196 \\
11.333 \\
1.502 \\
1.057 \\
1.043 \\
294\end{array}$ & $\begin{array}{c}1.13 \\
4.82 \\
4.4 \\
4.69 \\
8.15 \\
38.36 \\
28.6 \\
3.8 \\
2.67 \\
2.63 \\
0.75\end{array}$ & $\begin{array}{c}13 \\
25 \\
30 \\
42 \\
49 \\
190 \\
136 \\
18 \\
25 \\
26 \\
6\end{array}$ & $\begin{array}{l}2.32 \\
4.46 \\
5.36 \\
7.5 \\
8.75 \\
33.9 \\
24.3 \\
3.21 \\
4.5 \\
4.64 \\
1.07\end{array}$ \\
\hline Total & $\begin{array}{c}19,523 \\
(32.8 \%)\end{array}$ & 100 & $\begin{array}{c}39.617 \\
(66.3 \%)\end{array}$ & 100 & $\begin{array}{c}560 \\
(0.9 \%)\end{array}$ & 100 \\
\hline
\end{tabular}

Table 7: Distribution of deaths and lethality (= LET) according to type of spider by age group from 2009 to 2013 (total number of deaths)

\begin{tabular}{|c|c|c|c|c|c|c|}
\hline $\begin{array}{c}\text { Age } \\
\text { Groups }\end{array}$ & $\begin{array}{l}\text { Phoneutria } \\
\text { Deaths (\%) }\end{array}$ & $\begin{array}{c}\text { Phoneutria } \\
\text { LET. }\end{array}$ & $\begin{array}{l}\text { Loxosceles } \\
\text { Deaths (\%) }\end{array}$ & $\begin{array}{c}\text { Loxosceles } \\
\text { LET. }\end{array}$ & $\begin{array}{l}\text { Latrodectus } \\
\text { Deaths (\%) }\end{array}$ & $\begin{array}{c}\text { Latrodectus } \\
\text { LET. }\end{array}$ \\
\hline$<1$ & $0(0)$ & 0 & 0 & 0 & 0 & 0 \\
\hline $1-4$ & $0(0)$ & 0 & $2(11.11)$ & $0.1 \%$ & 0 & 0 \\
\hline $5-9$ & $0(0)$ & 0 & $2(11.11)$ & $0.11 \%$ & 0 & 0 \\
\hline $10-14$ & $2(40)$ & $0.22 \%$ & $1(5.56)$ & $0.05 \%$ & 0 & 0 \\
\hline $15-19$ & $0(0)$ & 0 & $1(5.56)$ & $0.03 \%$ & 0 & 0 \\
\hline $20-39$ & $0(0)$ & 0 & $5(27.77)$ & $0.03 \%$ & 0 & 0 \\
\hline $40-59$ & $0(0)$ & 0 & $4(22.22)$ & $0.03 \%$ & $1(100)$ & $0.73 \%$ \\
\hline $60-64$ & $1(20)$ & $0.11 \%$ & $2(11.11)$ & $0.13 \%$ & 0 & 0 \\
\hline $65-69$ & $1(20)$ & $0.11 \%$ & 0 & 0 & 0 & 0 \\
\hline $70-79$ & $0(0)$ & 0 & $1(5.56)$ & $0.09 \%$ & 0 & 0 \\
\hline$>80$ & $1(20)$ & $0.11 \%$ & 0 & 0 & 0 & 0 \\
\hline Total & $5(100)$ & $0.02 \%$ & $18(100)$ & 0.04 & $1(100)$ & $0.17 \%$ \\
\hline
\end{tabular}




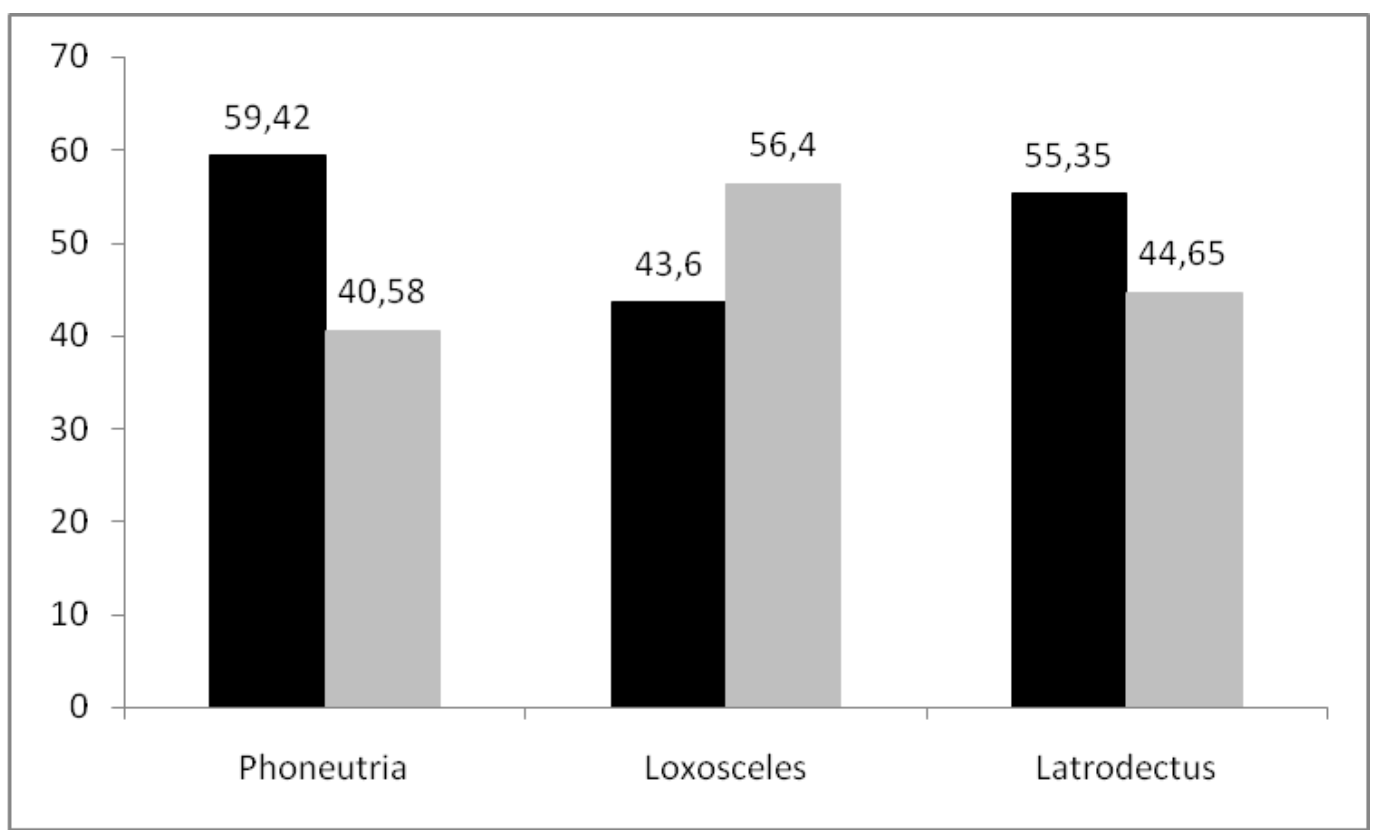

Figure 4: Percentage of male subjects (black columns) and female (gray columns) in accidents with spiders (Phoneutria = 19523 cases; Loxosceles = 39,624 cases; Latrodectus = 560 cases) in Brazil during the years 2009-2013

\section{DISCUSSION}

The main animal responsible for poisoning in Brazil was the scorpion (60,370.8 cases per year). Snakes were responsible for higher mortality (119 deaths per year) and lethality $(0.41 \%)$. When the lethality of snakebite is analysed by country region, we observed that it is higher in the Northeast $=$ $0.6 \%$, Central-West $=0.47 \%$, and North $=0.46 \%$ and lower in the South $=0.2 \%$ and Southeast $=$ $0.27 \%) .^{4}$ This shows the need for strategies to reduce the lethality rates in those regions where they are higher.

The main factor that may be contributing to problem of high lethality are the time elapsed between the accident and the serum therapy. ${ }^{13,14}$ Improvements in transportation of the victims from isolated places to the city centres could reduce those indicators. Many victims also misconduct the treatment or do not seek hospital care in cases of poisoning. ${ }^{3,4}$ This highlights the importance of educational campaigns on first aid and the importance of going to a hospital. Training of health professionals for the treatment of patients bitten by poisonous animals, according to the epidemiological situation and fauna of the region where it is located, 14,15 is another important recommendation.

Males aged from 20 to 59 were the main victims of snakebites, highlighting the importance of snakebite as an occupational health hazard, especially in agricultural activities. ${ }^{5}$ Little difference in the frequency of accidents with spiders and scorpions was observed when comparing men and women. This is probably because most cases of this type of poisoning occur in urban areas and in houses where these animals are found.10,16,17 People between 20 and 59 years were also the main victims in cases of poisoning by scorpions and spiders. This might be associated with activities such as household chores (cleaning yards and doing laundry) and handling construction debris and materials. ${ }^{18,19}$ A progressive increase in poisonings was observed from the first year of age until the age of 20-39 years, and after this, there is a decrease in all kinds of accidents.

As already reported in other studies on snakebites, 7,20 higher lethality rates were observed in the elderly and in children. Adults over age 50 are more likely to develop renal failure and adults over 60 are more likely to present with necrosis in the bite region. ${ }^{8}$ Children (under 10 years) have low immune capacity and less muscle mass than adults and can have more intense clinical symptoms of poisoning. ${ }^{21}$ They are also at increased risk of reactions to antivenom. ${ }^{22}$

Pregnant women accounted for $0.5 \%$ (about 150 cases per year) of victims of snakebites; this value is within the observed frequency $(0.4 \%$ to $1.8 \%)$ found in other studies conducted in South Africa, India and Sri Lanka. ${ }^{23}$ Despite this low frequency of cases, pregnancy had higher mortality $(1.33 \%)$ compared to the overall lethality in women $(0.39 \%)$.

In addition to the increased death rate of pregnant victims of snakebites, there is also a possibility of obstetric complications and risk to the foetus (vaginal bleeding, uterine contraction, threatened abortion, decrease in foetal movements and foetal death), ${ }^{23,24}$ which requires special attention for these patients.

Most cases of snakebite corresponded to bothropic accidents $(86.2 \%)$ when analysed by 
genus of snake followed by crotalic ( $9 \%)$, lachetic (3.9\%) and elapidic (0.9\%) accidents, a pattern that was expected and observed by Bernarde. ${ }^{4} \mathrm{~A}$ higher occurrence of elapid poisonings was observed in children between 1 and 4 years of age (4.95\%) in relation to accidents by other snakes $(1.55 \%$ to $1.76 \%$ ). Because the coral snake (Micrurus spp.) has a pattern of coloured rings, children who are unaware of the danger can be compelled to handle it and then are bitten. ${ }^{21}$

A higher proportion of males was bitten by bushmasters (Lachesis muta) $(81.76 \%$ ) and rattlesnakes (Crotalus durissus) ( $80.73 \%$ ), compared to cases of poisoning by lanceheads (Bothrops) (77.58\%) and coral snakes (Micrurus spp.) (71.06\%). This is probably related to the extra activity of men in forests where the Lachesis muta is and in areas of crops and pastures where Crotalus durissus is. Bothrops and Micrurus are also present in urban areas, ${ }^{4}$ promoting greater contact with women.

Young people under 14 years old had the highest mortality as well as lethality in scorpion accidents, demonstrating that children and adolescents are a higher risk group, as reported by Nunes et al., ${ }^{18}$ Soares et al., ${ }^{19}$ Guerra et al., ${ }^{25}$ and Bucaretchi et al. ${ }^{10}$ Because elderly persons have weakened immune systems, they are also a group at high risk for death and thereby require special attention. ${ }^{18,19}$

Accidents with spiders had lower lethality $(0.05 \%)$ compared to scorpion and snakes accidents. Oliveira et al. ${ }^{6}$ also reported this in Brazil for the period from 2000 to 2007 . The deaths are more common in adults aged from 20 to 59 years ( $50 \%$ of cases; average of 6.6 deaths per year), which are also the majority of victims (63\% of cases). A problem of araneism is the large proportion of cases in which there is no reference in the SINAN record to the type of spider that caused the accident (ignored/White). ${ }^{6}$ Only $46.3 \%$ of cases recorded the spider's genus; most of the cases were assigned to brown spider (Loxosceles; 66.3\%) followed by Phoneutria $(32.8 \%)$ and Latrodectus $(0.9 \%)$. There was a higher incidence of loxoscelism in women (56.4\%), probably due to the high number of brown spiders (Loxosceles) in urban areas and in homes of southern Brazil, where many accidents occur. 6,16 Regarding phoneutrism and latrodectism, most of the accidents occurred to men (59.42\% and $55.35 \%$ of cases, respectively), probably due to the greater male presence in agricultural activities in rural areas and in others (gardening and weeding) in the cities. ${ }^{6,12}$

In conclusion, because of approximately 115,000 cases per year in Brazil, accidents with snakes, scorpions and spiders have great importance in public health. There is a progressive increase of poisoning from the first year of age until the age of 20-39 years followed by a decrease in the number of cases.

Children and adolescents (under 14 years old) and older adults are the most vulnerable groups, because they have higher lethality rates, especially with regards to snake and scorpion accidents. Pregnant women have a higher lethality in cases of snakebites (1.33\%) and the possibility of obstetric complications.

Most cases of snakebites occurred in males, while there was little difference observed in frequency of accidents with scorpions and spiders when comparing men and women. This is probably related to the increased male activity in the countryside and forests, where most cases of snake bite occurs and is also due to the presence of arachnids in urban areas.

\section{REFERENCES}

1. Chippaux JP, Goyffon M. Epidemiology of scorpionism: A global appraisal. Acta Trop. 2008; 107(2): 71-9. Doi: http://dx.doi.org/ 10.1016/j.actatropica.2008.05.021

2. WHO - World Health Organization. List of neglected tropical diseases. 2014. [cited 2014 Nov 12] Available from: http://www.who.int/ neglected_diseases/diseases/en/.

3. SINAN/SVS/MS. Sistema de Informação de Agravos de Notificação - Sinan, Ministério da Saúde, 2014. [cited 2014 Nov 07] Available from: http://www.saude.gov.br/.
4. Bernarde PS. Serpentes peçonhentas e acidentes ofídicos no Brasil. São Paulo: Anolis Books; 2014.

5. Bochner R, Struchner CJ. Epidemiologia dos acidentes ofídicos nos últimos 100 anos no Brasil: uma revisão. Cad Saúde Pública. 2003;19(1): 7-16. DOI: http://dx.doi.org/ 10.1590/S0102-311X2003000100002

6. Oliveira RC, Wen FH, Sifuentes DN. Epidemiologia dos acidentes por animais peçonhentos. In: Cardoso JLC, França FOS, Wen FH, Málaque CMS, Haddad Jr.V. Animais peçonhentos no Brasil - Biologia, clínica e terapêutica dos acidentes. 2a ed. São Paulo: Sarvier; 2009; p. 6-21. 
7. Ribeiro LA, Albuquerque MJ, Pires-de-Campos VAF, Katz G, Takaoka NY, Lebrão ML, et al. Óbitos por serpentes peçonhentas no estado de São Paulo: avaliação de 43 casos, 1988/93. Rev Ass Med Bras. 1998; 44(4):312-318. Doi: http://dx.doi.org/10.1590/S010442301998000400010.

8. Ribeiro LA, Gadia R, Jorge MT. Comparação entre a epidemiologia do acidentes e a clínica do envenenamento por serpentes do gênero Bothrops em adultos idosos e não idosos. Rev Soc Bras Med Trop. 2008; 41(1): 46-49. Doi: h t t p : / / dx.doi.org/10.1590/S0037 86822008000100009.

9. Caiaffa WT, Vlahov D, Antunes CMF, Oliveira $H R$, Diniz CR. Snake bite and antivenom complications in Belo Horizonte, Brazil. Trans R Soc Trop Med Hyg. 1994; 88(1): 81-85. Doi: http: //dx.doi.org/10.1016/0035 9203(94)90511-8

10. Bucaretchi F, Fernandes LCR, Fernandes CB, Branco MM, Prado CC, Vieira RJ, et al. Clinical consequences of Tityus bahiensis and Tityus serrulatus scorpion stings in the region of Campinas, southeastern Brazil. Toxicon. 2014; 89:17-25. Doi: http://dx.doi.org/10.1016/ 0035-9203(94)90511-8.

11. Pardal PPO, Ishikawa EAY, Vieira JLF, Coelho JS, Dórea RCC, Abati PAM, et al. Clinical aspects of envenomation caused by Tityus obscurus (Gervais, 1843) in two distinct regions of Pará state, Brazilian Amazon basin: a prospective case series. J Venom Anim Toxins Incl Trop Dis. 2014; 20(1): 3. Doi: http:// dx.doi.org/10.1186/1678-9199-20-3.

12. Lira-da-Silva RM, Matos GB, Sampaio RO, Nunes TB. Estudo retrospectivo de latrodectismo na Bahia, Brasil. Rev Soc Bras Med Trop. 1995; 28(3):205-210. Doi: http://dx.doi.org/ 10.1590/S0037-86821995000300007

13. Borges CC, Sadahiro M, Santos MC. Aspectos epidemiológicos e clínicos dos acidentes ofídicos ocorridos nos municípios do Estado do Amazonas. Rev Soc Bras Med Trop. 1999; 32(6): 637-646. Doi: http://dx.doi.org/ 10.1590/S0037-86821999000600005.

14. Bernarde PS, Gomes JO. Serpentes peçonhentas e ofidismo em Cruzeiro do Sul, Alto Juruá, Estado do Acre, Brasil. Acta Amaz. 2012; 42(1): 65-72. Doi: http://dx.doi.org/ 10.1590/S0044-59672012000100008.

15. Mise YF, Lira-da-Silva RM, Carvalho FM. Envenenamento por serpentes do gênero Bothrops no estado da Bahia: aspectos epidemiológicos e clínicos. Rev Soc Bras Med Trop. 2007; 40(5): 569-573. Doi: http://dx.doi.org/10.1590/ S0037-86822007000500015

16. Fisher ML, Vasconcellos-Neto J. Microhabitats Occupied by Loxosceles intermedia and Loxosceles laeta (Araneae: Sicariidae) in Curitiba, Paraná, Brazil. J Med Entomol. 2005; 42(5): 756-765. Doi: http://dx.doi.org/ 10.1093/jmedent/42.5.756.

17. Brazil TK, Pinto-Leite CM, Almeida-Silva LM, Lira-da-Silva RM, Brescovit AD. Aranhas de importância médica do estado da Bahia, Brasil. Gaz. Méd Bahia. 2009; 79(Supl. 1): 32-37.

18. Nunes CS, Bevilacqua PD, Jardim CCG. Aspectos demográficos e espaciais dos acidentes escorpiônicos no Distrito Sanitário Noroeste, município de Belo Horizonte, Minas Gerais, 1993 a 1996. Cad Saúde Pública. 2000; 16(1): 213223. Doi: http://dx.doi.org/10.1590/S0102311X2000000100022.

19. Soares MRM, Azevedo CS, Maria M. Escorpionismo em Belo Horizonte, MG: um estudo retrospectivo. Rev Soc Bras Med Trop. 2002; 35(4): 359-363. Doi: http://dx.doi.org/ 10.1590/S0037-86822002000400013.

20. França FOS, Málaque CMS. Acidente botrópico. Pp. 81-95 In: Cardoso JLC, França FOS, Wen FH, Málaque CMS, Haddad Jr. V. Animais peçonhentos no Brasil - Biologia, clínica e terapêutica dos acidentes. $2^{a}$ ed. São Paulo: Sarvier; 2009.

21. Cavazos MEO, Garza CR, Guajardo-Rodríguez G, Hernández-Montelongo BA Montes-Tapia FD. Snake bites in pediatric patients, a current view. Complementary Pediatrics . 2012; p. 123-136. Doi: http://dx.doi.org/10.5772/34749.

23. Langley RL. Snakebite during pregnancy: a literature review. Wilderness Environ Med. 2010; 21(1): 54-60. Doi: http://dx.doi.org/ 10.1016/j.wem.2009.12.025.

24. Pardal PPO, Mazzeo T, Pinheiro ACL. Snakebite in pregnancy: a preliminary study. J Venom Anim Toxins. 1997; 3(2): 280-286. Doi: http:/ /dx.doi.org/10.1590/S0104-7930199 7000200004.

25. Guerra CMN, Carvalho LFA, Colosimo EA, Freire HBM. Análise de variáveis relacionadas à evolução letal do escorpionismo em crianças e adolescentes no estado de Minas Gerais no período de 2001 a 2005. J Pediatr. 2008; 84(6): 509: 515. Doi: http://dx.doi.org/10.1590/ s0021-75572008000700007. 


\section{RESUMO}

Introdução: acidentes com animais peçonhentos são uma emergência clínica frequente em vários países tropicais, principalmente nos campos e áreas rurais, constituindo um problema de Saúde Pública, inclusive pediátrica. Objetivo: analisar a morbidade, mortalidade e letalidade de acordo com a faixa etária e sexo nos casos de envenenamentos por serpentes, escorpiões e aranhas no Brasil. Método: Os dados sobre envenenamentos por serpentes, escorpiões e aranhas ocorridos no período de 2009 a 2013 foram obtidos na base de dados online do Sistema de Informação de Agravos de Notificação - SINAN do Ministério da Saúde. Resultados: foi registrada uma média de 28.812 casos por ano de acidentes ofídicos, $60.370,8$ com escorpiões e $25.786,4$ com aranhas. A maioria dos óbitos foi causada por serpentes (119 por ano) e também apresentou maior letalidade $(0,41 \%)$, seguida por escorpiões (79,6 óbitos) com letalidade de $0,13 \%$ e, aranhas $(13,2)$ com menor letalidade $(0,05 \%)$. Em indivíduos do sexo masculino ocorreram a maioria dos casos de acidentes ofídicos, enquanto que nos acidentes com escorpiões e aranhas foi observado pouca diferença na frequência entre homens e mulheres. A faixa etária com maior número de registros de envenenamentos foi a de 20 a 39 anos. Conclusões: ocorre um aumento progressivo de casos de envenenamentos a partir do primeiro ano de idade até a faixa etária compreendida entre 20 a 39 anos e após esta, começa uma diminuição. Crianças, adolescentes e adultos idosos, constituem grupos mais vulneráveis por apresentarem maiores índices de letalidade, especialmente nos acidentes ofídicos e escorpiônicos.

Palavras-chaves: acidentes ofídicos, ofidismo, escorpionismo, araneísmo. 